\title{
Antibacterial Activity of Green Synthesis of Iron Nanoparticles Using Lawsonia inermis and Gardenia jasminoides Leaves Extract
}

\author{
Tayyaba Naseem and Muhammad Akhyar Farrukh \\ Nanochemistry Laboratory, Department of Chemistry, GC University Lahore, Lahore 54000, Pakistan \\ Correspondence should be addressed to Muhammad Akhyar Farrukh; akhyar100@gmail.com
}

Received 22 November 2014; Accepted 29 December 2014

Academic Editor: Mallikarjuna N. Nadagouda

Copyright ( 92015 T. Naseem and M. A. Farrukh. This is an open access article distributed under the Creative Commons Attribution License, which permits unrestricted use, distribution, and reproduction in any medium, provided the original work is properly cited.

\begin{abstract}
Recently, development of reliable experimental protocols for synthesis of metal nanoparticles with desired morphologies and sizes has become a major focus of researchers. Green synthesis of metallic nanoparticles has accumulated an ultimate interest over the last decade due to their distinctive properties that make them applicable in various fields of science and technology. Metal nanoparticles that are synthesized by using plants have emerged as nontoxic and ecofriendly. In this study a very cheap and simple conventional heating method was used to obtain the iron nanoparticles (FeNPs) using the leaves extract of Lawsonia inermis and Gardenia jasminoides plant. The iron nanoparticles were characterized by thermal gravimetric analysis (TGA), Fourier transform infrared spectroscopy (FT-IR), transmission electron microscopy (TEM), scanning electron microscopy (SEM), atomic force microscopy (AFM), and X-ray diffraction (XRD). The antibacterial activity was studied against Escherichia coli, Salmonella enterica, Proteus mirabilis, and Staphylococcus aureus by using well-diffusion method.
\end{abstract}

\section{Introduction}

Nanoparticles are considered as important structural masses of nanotechnology. The unique and most important property of the nanoparticles is that they unveil superior activity. There are remarkable applications of metal nanoparticles in the areas of diagnostic biological probes, catalysis, display devices, and optoelectronics [1]. The widespread practical application of metal nanoparticles $(<100 \mathrm{~nm})$ is attributable to a number of their unique properties [2-5]. Metal nanoparticles are widely synthesized using physical and chemical processes, which allow one to acquire particles with the preferred characteristics [6-8]. Several methods like hydrothermal [9], conventional heating [10], anodization [11], deposition precipitation [12], wet oxidation [13], electrodeposition [14], and sonication [15] are being applied to synthesize the nanoparticles. However, these production methods are usually expensive and labor-intensive and are potentially hazardous to the environment and living organisms.

Green synthesis has advances over chemical and physical method as it is cost operative, atmosphere friendly, and easily scrabbled up for large scale synthesis and in this method there is no need to use high energy, temperature, and toxic chemicals. Green synthesis offer better influence, control over crystal growth and their steadiness. Green synthesized nanoparticles are cheap and economical and have many applications in science [16-19].

From the dawn of civilization, human beings have used various medicinal plants to fight diseases [20]. Lawsonia inermis is a dwarf shrub, commonly known as "Mehndi or Henna" in Pakistan. It is renowned worldwide due to its cosmetic use for the reason of exclusive active principles in the leaves. It contains different variety of molecules which are bioactive. It is believed to decrease body temperature in situation of high fever and give beautiful and healthy hair. Lawsonia inermis is grown in various dry tropical and subtropical areas of North Africa, South Asia, South East Asia, and the Middle East [21]. Strong antimicrobial, anticancer, anti-inflammatory, analgesic, antiparasitic, and virucidal properties of this plant have been reported [22]. Lawsonia inermis leaves were studied for their antimicrobial prospective and they exhibited notable 
antibacterial activity against Gram-negative bacterial strains [23].

Gardenia jasminoides Ellis is a flowering plant, which has its place in genus Gardenia and family Rubiaceae. Traditionally, in many Asian countries it has been used as a folk medicine [24]. This plant has numerous medicinal uses for treating hemorrhage, jaundice, toothaches, hepatitis, sprains, wounds, and skin conditions [25-27]. As a hemostatic agent, Gardenia is very active as well in handling injuries of the joints, tendons, and muscles. "Crocetin" is an extracted chemical compound from the Gardenia berry, from which a yellow-silk dye has been made for this treatment [28].

In nanometer size metallic nanoparticles, iron has received special attention because of its physical and chemical properties which are determined by its size, shape, composition, crystallinity, and structure [29]. Bimetallic iron and silver containing nanoparticles (Fe-Ag NPs) have numerous applications in optical, medical, and remediation fields [30]. Iron nanoparticles can also be used as oxidant for the synthesis of multiwalled carbon nanotubes- (MWCNTs-) core/thiophene polymer-sheath composite nanocables in the presence of cationic surfactant, decyl trimethyl ammonium bromide (DTAB) [31]. Against the bacterial strains causing digestive problems, iron nanoparticles of corn flakes-like morphology gave excellent antibacterial activity [32].

Bacterial resistance to various antibiotics is a serious clinical dilemma, so different antimicrobial activities were performed using plants as a source. The development in the field of green chemistry has delivered different nanomaterials as substitute antibacterial agents. In this present study, an effort is made to synthesize iron nanoparticles using leaves extract of Lawsonia inermis and Gardenia jasminoides as reducing agent. The characterization of green synthesized iron nanoparticles was characterized by thermal gravimetric (TGA), transmission electron microscopy (TEM), scanning electron microscopy (SEM), Fourier transform infrared spectroscopy (FT-IR), X-ray diffraction (XRD), and atomic force microscopy (AFM). Also antibacterial activity was studied against human pathogenic Gram-negative (Escherichia coli, Salmonella enterica, and Proteus mirabilis) and Gram-positive (Staphylococcus aureus) bacterial strains.

\section{Materials and Methods}

Fresh leaves of Henna and Gardenia plants were collected from various botanical gardens of Lahore, Pakistan. Sulfuric acid (conc.) and iron sulphate $\left(\mathrm{FeSO}_{4}\right)$ were purchased from Merck and all chemicals were used short of any further purification. CORNING (PC-420D) hot plate was used to maintain the temperature in the synthesis process. Various techniques were used to characterize the synthesized samples, that is, Fourier transform infrared spectroscopy (FTIR) on MIDAC M2000 which identified various functional groups present in extract and which determined the presence of metal, powder X-ray diffractometer (XRD) of X'pert PRO, and PANalytical, equipped with a copper anode source generating $\mathrm{X}$-rays having wavelength equal to $1.54 \AA$. The elemental composition and morphology were investigated by using scanning electron microscope-energy-dispersive X-ray spectroscopy (SEM-EDX) on Hitachi S3400 on an accelerating voltage of $15.0 \mathrm{kV}$. The size of synthesized sample particles was determined by transmission electron microscope (TEM) of Phillip CM12 microscope.

2.1. Preparation of Powder. Fresh leaves of Henna and Gardenia plants were softly eroded in deionized water by which the dust particles were removed and plants material was then placed to dry under sunlight for seven days. All of the dried leaves of plants were ground using grinder, pastel, and mortar. After the process of grinding the leaves powder went through sieving to get very fine particles of uniform size. Nanoparticles were synthesized by using sieved powder.

2.2. Preparation of FeNPs. A simple conventional heating method was used in the synthesis of iron nanoparticles (FeNPs) by using plant extract. Plant extract was prepared by dissolving $2 \mathrm{gm}$ of the sieved powder in $50 \mathrm{~mL}$ of deionized water and the resulting mixture kept on stirring for 3 hours by using the magnetic stirrer. The resulting solution was placed to stable for 1 hour and then filtered. $10 \mathrm{~mL}$ of $0.01 \mathrm{M} \mathrm{FeSO}_{4}$ solution was used in which plant extract (filtrate) was added after every interval of 5 minutes using $2 \mathrm{~mL}$ in each interval until $50 \mathrm{~mL}$; resulting mixture was stirred at $70^{\circ} \mathrm{C}$. The difference of temperature was noted after every interval of $5 \mathrm{~min}$ utes. The solution was placed to cool down and the product was parted by centrifugation $(10,000 \mathrm{rpm})$ for 2 minutes. The product was dried at $50^{\circ} \mathrm{C}$ for 3 hours. The plant extract (filtrate) acts as reducing, capping, and stabilizing agent in iron nanoparticles synthesis [33].

2.3. Antibacterial Studies. Three human pathogenic Gramnegative (Escherichia coli, Salmonella enterica, and Proteus mirabilis) and one Gram-positive (Staphylococcus aureus) bacterial strains were used for antimicrobial study of iron nanoparticles by well-diffusion method [34-36]. The bacterial strains were grown in Luria-Bertani (LB) at $37^{\circ} \mathrm{C}$ with continuous shaking at $200 \mathrm{rpm}$ for 24 hours. $100 \mu \mathrm{L}$ from each bacterial culture was spread on LB agar plates with the help of L-shaped glass spreader. Three wells were developed in each plate with the help of sterilized steel borer of $8 \mathrm{~mm}$ diameter and $30 \mu \mathrm{L}$ sample suspension was loaded in each well. The plates were incubated for 24 hours at $37^{\circ} \mathrm{C}$. Diameter of the inhibition zones was recorded in $\mathrm{mm}$. The experiment was repeated thrice and the average values were calculated for antibacterial activity.

\section{Results and Discussion}

3.1. TGA of FeNPs Synthesized Using Henna and Gardenia Leave Extract. The weight losses were $12 \%$ at $60-205^{\circ} \mathrm{C}$ and $31 \%$ at $280-510^{\circ} \mathrm{C}$ which were due to the removal of moisture, hydrogen, and three oxygen molecules present in coumaric acid (chemical constituent in Henna), respectively, as shown in Figure 1.

Figure 2 represents the TGA for the FeNPs synthesized using Gardenia plant extract. Initial weight was lost at $7 \%$ 


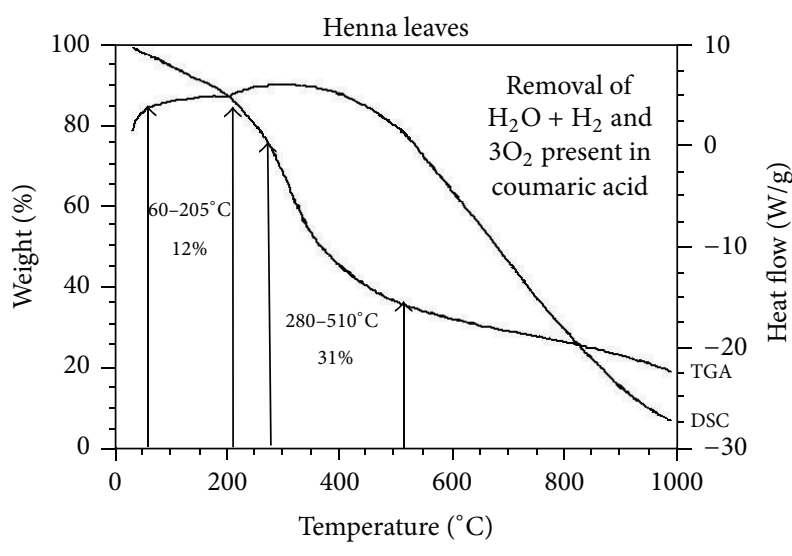

Figure 1: TGA of FeNPs synthesized using Henna leaves extract.

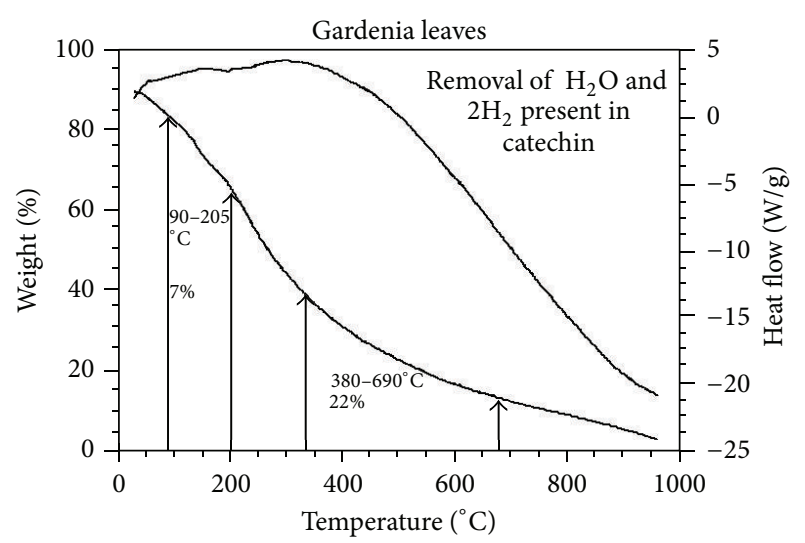

FIgURE 2: TGA of FeNPs synthesized using Gardenia plant extract.

at $90-205^{\circ} \mathrm{C}$ because of removal of moisture, two hydrogen molecules present in catechin (chemical constituent of Gardenia). Second weight loss was $22 \%$ at $340-690^{\circ} \mathrm{C}$ and represents the removal of two oxygen molecules present in ferric sulphate used.

\subsection{FTIR Analysis of FeNPs Synthesized Using Henna and Gar-} denia Leaves Extract. The main constituent of Henna extract is Lawson (2-hydroxy-1,4-naphthoquinone). It contains benzene unit, p-benzoquinone unit, and phenolic group. The Henna extract was evaporated to dryness to get a solid mass. Its FTIR spectrum is shown in Figure 3 [37].

The phenolic O-H stretch appeared at 3302.38$3264.84 \mathrm{~cm}^{-1}$. The aromatic $\mathrm{C}=\mathrm{C}$ stretching frequency which appeared at $1539.81 \mathrm{~cm}^{-1}$ is due to $\mathrm{p}$-coumaric acid present in the sample. The $\mathrm{C}=\mathrm{O}$ stretching frequency appeared at $1622.64 \mathrm{~cm}^{-1}$. Thus Lawson was characterized by IR spectroscopy. It was inferred that Lawson has coordinated with $\mathrm{Fe}^{0}$ through the phenolic oxygen, aromatic ring, and $\mathrm{C}=\mathrm{O}$ group of the p-benzoquinone resulting in the formation of $\mathrm{Fe}^{0}$ which have Lawson as capping and stabilizing agent on the anodic sites of the metal surface. The band at $612.63 \mathrm{~cm}^{-1}$

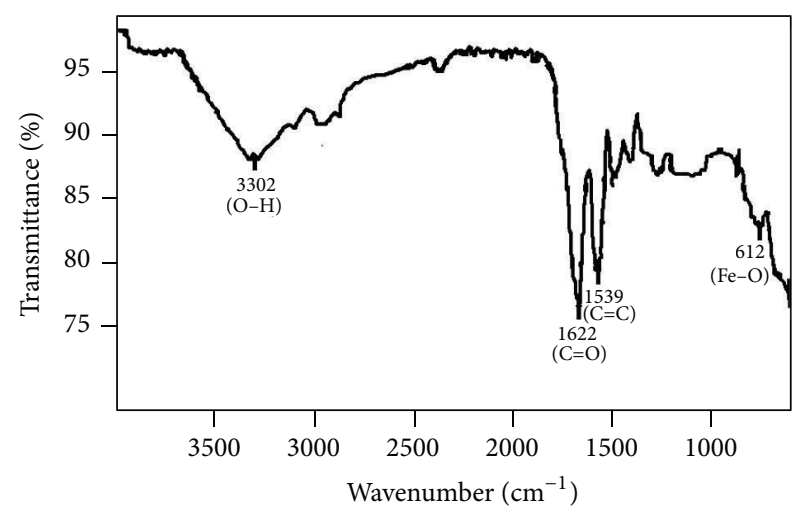

FIgURE 3: FTIR spectra of FeNPs synthesized using Henna leaves extract.

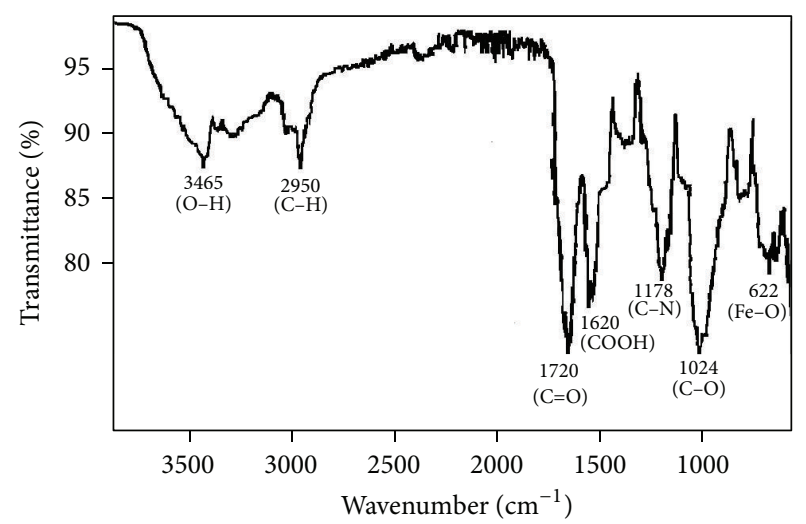

FIGURE 4: FTIR spectra of FeNPs synthesized using Gardenia leaves extract.

was due to Fe as shown in Figure 3. Thus FTIR spectral study leads to the conclusion that the fingermark film consists of $\mathrm{Fe}^{0}$ Lawson complex [38].

The FTIR spectra of Fe nanoparticles synthesized with Gardenia leave extract are given in Figure 4. The broad absorption band in the region from 3400 to $3200 \mathrm{~cm}^{-1}$ represents -OH group stretching and another peak at $2700 \mathrm{~cm}^{-1}$ represents $\mathrm{C}-\mathrm{H}$ stretching. The bands at 1647.28 and $1521.71 \mathrm{~cm}^{-1}$ may be assigned, respectively, to a $\mathrm{C}=\mathrm{O}$ stretching vibration band $(\mathrm{C}=\mathrm{O})$ and a coupled vibration involving the bending and the $\mathrm{C}-\mathrm{N}$ stretching modes of the amido bond of the biomass. The peak at $1032.47 \mathrm{~cm}^{-1}$ is corresponding to the vibrations of C-O in C-CCOOR. The band at $612.63 \mathrm{~cm}^{-1}$ was due to $\mathrm{Fe}$ vibrations.

3.3. XRD Analysis of FeNPs Synthesized Using Henna and Gardenia Leaves Extract. The nature and phase composition of FeNPs were identified by X-ray powder diffractometer with Bragg's angle ranging from $10^{\circ}$ to $70^{\circ}$. The presence of Fe in nanopowder was confirmed by a series of reflection angles $(2 \theta)$ at $44.34^{\circ}$ and $64.43^{\circ}$ having hkl values (111), (200), and (202) [39], respectively, with cubic plane of Fe [40] as shown in Figure 5. 


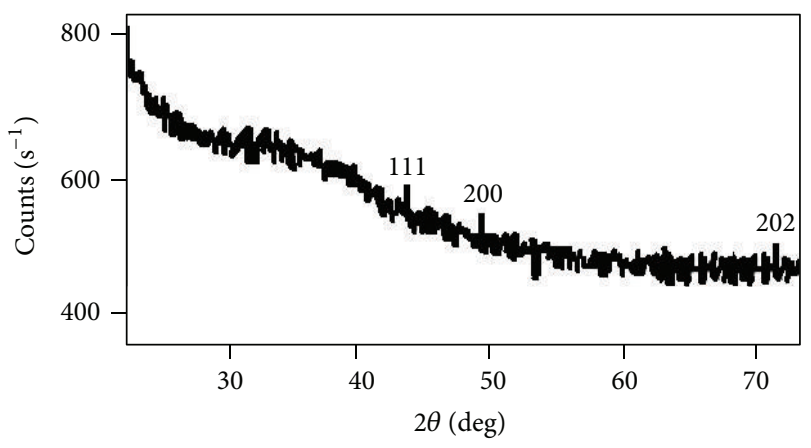

FIGURE 5: XRD pattern of FeNPs synthesized using Henna leaves extract.

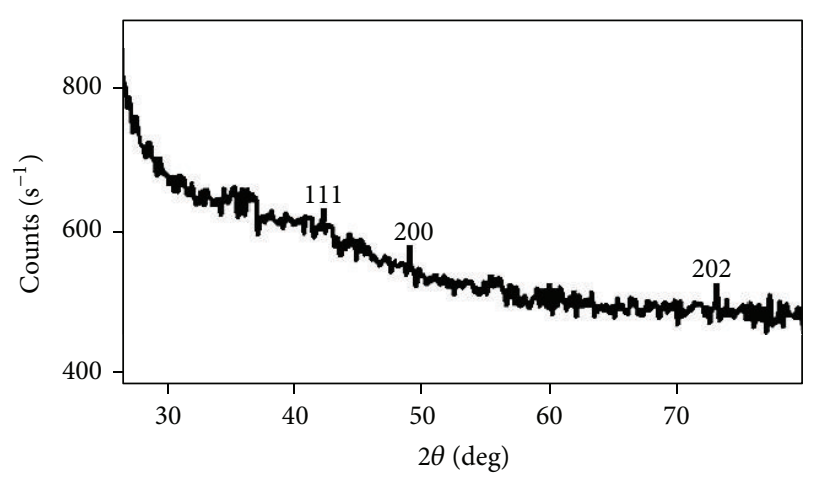

FIGURE 6: XRD pattern of FeNPs synthesized using Gardenia leaves extract.

The presence of Fe in nanopowder synthesized by Gardenia leave extract was confirmed by a series of reflection angles $(2 \theta)$ at $44.34^{\circ}$ and $64.43^{\circ}$ having hkl values (111), (200) and (202) [39], respectively, with cubic plane of Fe [40] as shown in Figure 6.

\subsection{TEM Image of FeNPs Using Henna and Gardenia Leaves} Extract. TEM analysis of the FeNPs was performed which were formed by using the Henna leaves extract and $\mathrm{FeSO}_{4}$ salt solution. The size of iron nanoparticles synthesized using Henna leaves extract was calculated as $21 \mathrm{~nm}$ as shown in Figure 7. While particle size of the same was observed as $32 \mathrm{~nm}$ when synthesized using the Gardenia leaves extract as shown in Figure 8.

\subsection{SEM-EDX Analysis of FeNPs Synthesized Using Henna and} Gardenia Leaves Extract. FeNPs synthesized using extract of leaves of Henna plant are studied under SEM. It indicates that nanoparticles formed are agglomerated because of the adhesive nature having morphology of distorted hexagonallike appearance as shown in Figure 9(a).

Elemental composition of FeNPs synthesized using Henna leaves extract was determined by using EDX analysis. It was observed that the percentage of iron is $6.86 \%$, carbon is $54.59 \%$, oxygen is $36.57 \%$, magnesium and phosphorus are $0.68 \%$, and potassium is $0.63 \%$ as shown in Figure 9(b). $\mathrm{Mg}$ and carbon are due to plant constituents.

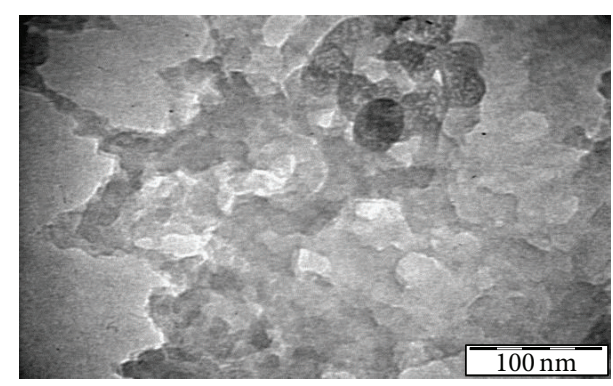

FIGURE 7: TEM analysis of FeNPs synthesized using Henna leaves extract.

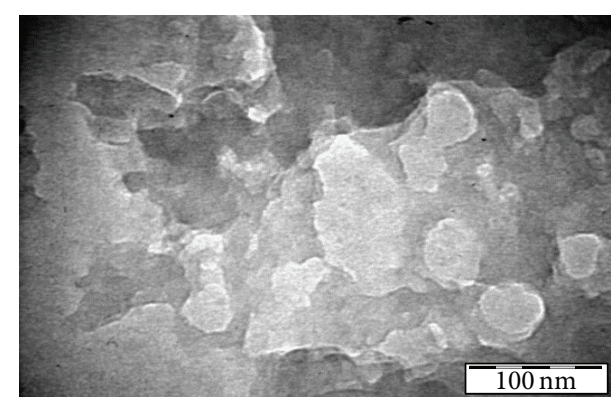

FIGURE 8: TEM image of FeNPs synthesized using Gardenia leaves extract.

FeNPs synthesized using extract of leaves of Gardenia plant are studied under SEM and shown in Figure 10(a). It indicates that nanoparticles formed are agglomerated because of the adhesive nature having morphology of shattered rock-like appearance.

Elemental composition of FeNPs synthesized using Gardenia leaves extract was also determined by using EDX analysis.

Elemental composition was found as percentage of iron is $4.68 \%$, carbon is $50.79 \%$, oxygen is $41.37 \%$, aluminium is $0.76 \%$, silicon is $1.57 \%$, and potassium is $0.83 \%$ as shown in Figure 10(b).

3.5.1. Antibacterial Results. Iron nanoparticles were synthesized using five different plants, that is, Lawsonia inermis, Gardenia jasminoides, Azadirachta indica, and Camellia sinensis leaves extract and Cinnamon zeylanicum barks extract and it was found that all are susceptible to all bacterial strains. Here we are representing the results of mainly the two of them, that is, iron nanoparticles synthesized using Lawsonia inermis and Gardenia jasminoides (Table 1) and the comparison is given in Figure 11. FeNPs of Gardenia jasminoides were more potent against Staphylococcus aureus with zone of inhibition (ZOI) $16 \mathrm{~mm}$, whereas for Lawsonia inermis it was $15 \mathrm{~mm}$ as shown in Figure 12. Against Escherichia coli, Salmonella enterica, and Proteus mirabilis the ZOI of iron nanoparticles of Lawsonia inermis and Gardenia jasminoides leaves extract was $14 \mathrm{~mm}$ and $15 \mathrm{~mm}, 9 \mathrm{~mm}$ and $12 \mathrm{~mm}, 11 \mathrm{~mm}$ and $13 \mathrm{~mm}$, respectively. 


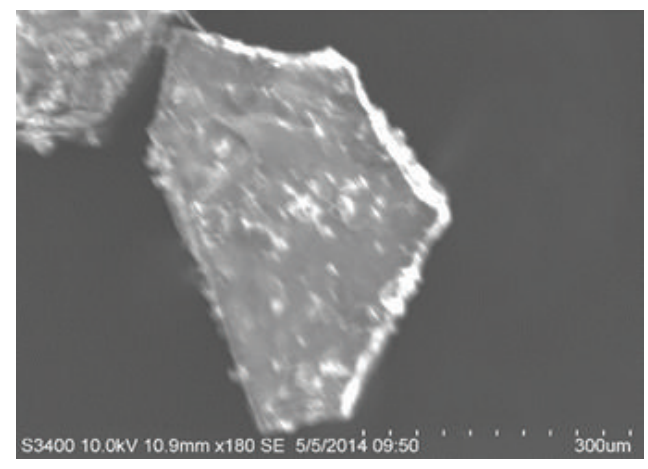

(a)

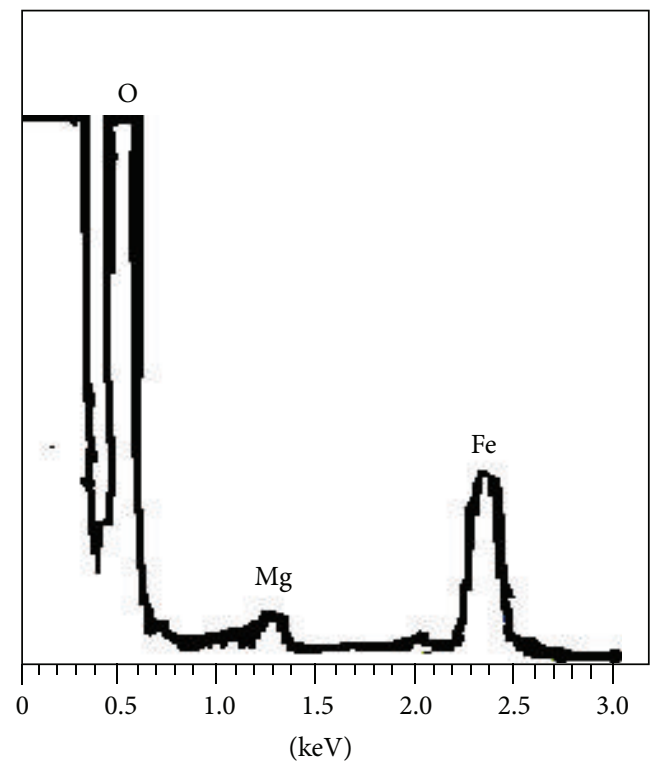

(b)

FIGURE 9: (a) SEM image and (b) EDX graph of FeNPs synthesized using Henna leaves extract.

TABLE 1: Antibacterial activity of iron nanoparticles of Lawsonia inermis and Gardenia jasminoides leaves extract $(30 \mu \mathrm{L} / \mathrm{mL})$.

\begin{tabular}{lcc}
\hline Microorganisms & \multicolumn{2}{c}{ Leaves extract } \\
& $\begin{array}{c}\text { Lawsonia inermis } \\
\text { Zone of inhibition (mm) }\end{array}$ \\
\hline Bacterial strains & & \\
E. coli (-) & 14 & 15 \\
S. enterica (-) & 09 & 12 \\
P. mirabilis (-) & 11 & 13 \\
S. aureus (+) & 15 & 16 \\
\hline
\end{tabular}

\section{Conclusion}

Due to the rich biodiversity of plants, the green world has potential for the synthesis of noble metal nanoparticles. Iron nanoparticles with an average size of $21 \mathrm{~nm}$ and $32 \mathrm{~nm}$ were synthesized using Lawsonia inermis and Gardenia jasminoides leaves extract, respectively. Green synthesized iron nanoparticles in the present study show good antibacterial

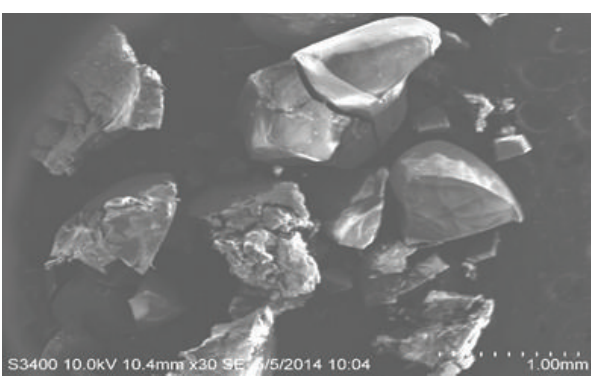

(a)

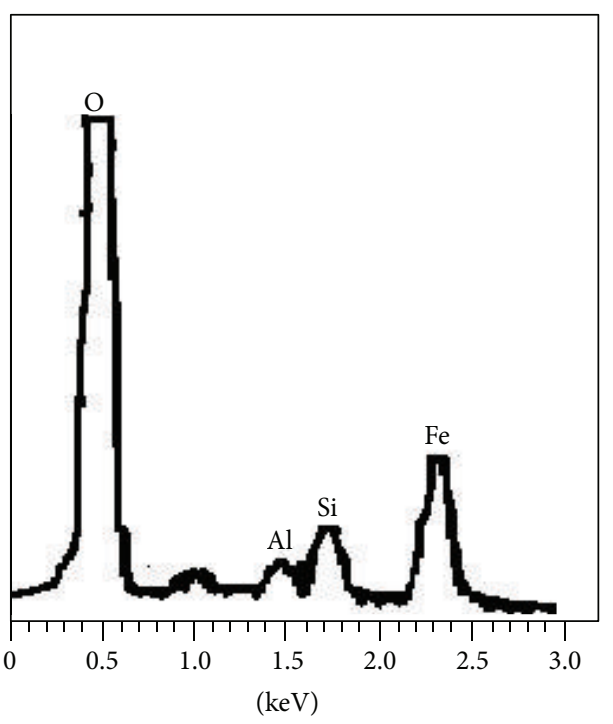

(b)

FIgURE 10: (a) SEM image and (b) EDX graph of FeNPs synthesized using Gardenia leaves extract.

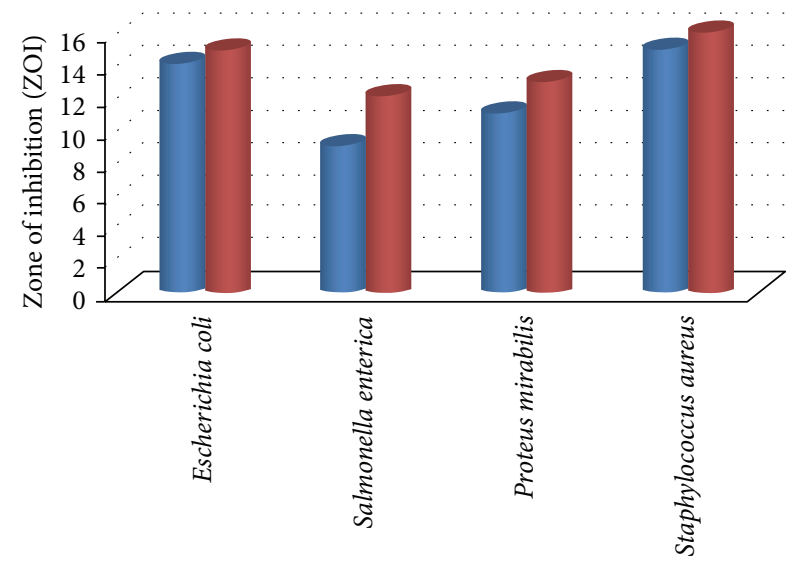

Bacterial strains

Lawsonia inermis

Gardenia jasminoides

FIGURE 11: Comparison of antibacterial activity of iron nanoparticles of Lawsonia inermis and Gardenia jasminoides leaves extract against bacterial strains.

activity against the human pathogens Escherichia coli and Staphylococcus aureus. As Lawsonia inermis and Gardenia 


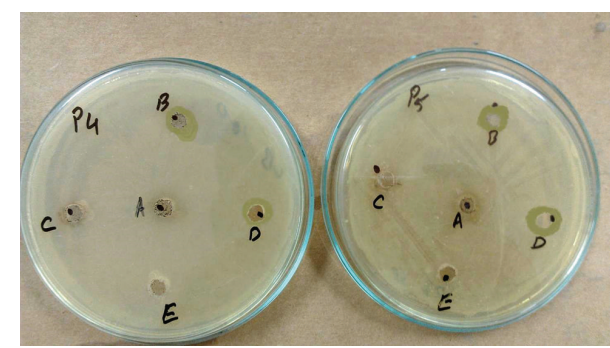

(a)

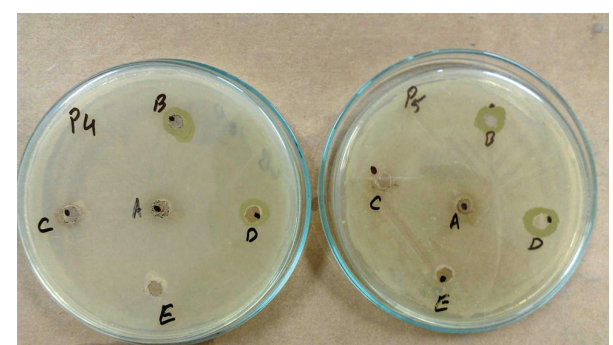

(b)

Figure 12: (a) Zone inhibition of FeNPs against $\mathrm{P}_{4}=$ Escherichia coli, $\mathrm{P}_{5}=$ Salmonella enterica, $\mathrm{B}=$ Lawsonia inermis, and D $=$ Gardenia jasminoides. (b) Zone inhibition of FeNPs against $\mathrm{P}_{4}=$ Staphylococcus aureus, $\mathrm{P}_{5}=$ Proteus mirabilis, $\mathrm{B}=$ Lawsonia inermis, and D $=$ Gardenia jasminoides.

jasminoides have been used in folk medicines, these green iron nanoparticles of Lawsonia inermis and Gardenia jasminoides have potential biomedical activities and have several paybacks such as suitability for medical and pharmaceutical submissions.

\section{Conflict of Interests}

The authors declare that there is no conflict of interests regarding the publication of this paper.

\section{References}

[1] J. Wagner, T. Kirner, G. Mayer, J. Albert, and J. M. Köhler, "Generation of metal nanoparticles in a microchannel reactor," Chemical Engineering Journal, vol. 101, no. 1-3, pp. 251-260, 2004.

[2] M. C. Roco, "Nanotechnology: convergence with modern biology and medicine," Current Opinion in Biotechnology, vol. 14, no. 3, pp. 337-346, 2003.

[3] L. Zhang, F. X. Gu, J. M. Chan, A. Z. Wang, R. S. Langer, and O. C. Farokhzad, "Nanoparticles in medicine: therapeutic applications and developments," Clinical Pharmacology and Therapeutics, vol. 83, no. 5, pp. 761-769, 2008.

[4] M.-C. Daniel and D. Astruc, "Gold nanoparticles: assembly, supramolecular chemistry, quantum-size-related properties, and applications toward biology, catalysis, and nanotechnolog," Chemical Reviews, vol. 104, no. 1, pp. 293-346, 2004.

[5] T. S. Wong and U. Schwaneberg, "Protein engineering in bioelectrocatalysis," Current Opinion in Biotechnology, vol. 14, no. 6, pp. 590-596, 2003.

[6] J. H. Fendler, Ed., Nanoparticles and Nanostructured Films: Preparation, Characterization and Applications, John Wiley \& Sons, New York, NY, USA, 1998.

[7] A. Panáček, L. Kvítek, R. Prucek et al., "Silver colloid nanoparticles: synthesis, characterization, and their antibacterial activity," The Journal of Physical Chemistry B, vol. 110, no. 33, pp. 1624816253, 2006.

[8] S. Kundu, V. Maheshwari, S. Niu, and R. F. Saraf, "Polyelectrolyte mediated scalable synthesis of highly stable silver nanocubes in less than a minute using microwave irradiation," Nanotechnology, vol. 19, no. 6, Article ID 065604, 2008.

[9] H. Perveen, M. A. Farrukh, M. Khaleeq-ur-Rahman, B. Munir, and M. A. Tahir, "Synthesis, structural properties and catalytic activity of $\mathrm{MgO}-\mathrm{SnO}_{2}$ nanocatalysts," Russian Journal of Physical Chemistry A, vol. 89, no. 1, pp. 99-107, 2015.

[10] M. Shahid, M. A. Farrukh, A. A. Umar, and M. Khaleeq-UrRahman, "Solvent controlled synthesis of $\mathrm{CaO}-\mathrm{MgO}$ nanocomposites and their application in the photodegradation of organic pollutants of industrial waste," Russian Journal of Physical Chemistry A, vol. 88, no. 5, pp. 836-844, 2014.

[11] M. A. Farrukh, C.-K. Thong, R. Adnan, and M. A. Kamarulzaman, "Preparation and characterization of zinc oxide nanoflakes using anodization method and their photodegradation activity on methylene blue," Russian Journal of Physical Chemistry A, vol. 86, no. 13, pp. 2041-2048, 2012.

[12] H. Yazid, R. Adnan, and M. A. Farrukh, "Gold nanoparticles supported on titania for the reduction of $p$-nitrophenol," Indian Journal of Chemistry -Section A Inorganic, Physical, Theoretical and Analytical Chemistry, vol. 52, no. 2, pp. 184-191, 2013.

[13] K. M. A. Saron, M. R. Hashim, and M. A. Farrukh, "Stress control in $\mathrm{ZnO}$ films on $\mathrm{GaN} / \mathrm{Al}_{2} \mathrm{O}_{3}$ via wet oxidation of $\mathrm{Zn}$ under various temperatures," Applied Surface Science, vol. 258, no. 13, pp. 5200-5205, 2012.

[14] E. M. Mkawi, K. Ibrahim, M. K. M. Ali, M. A. Farrukh, and A. S. Mohamed, "Synthesized and characterization of $\mathrm{Cu}_{2} \mathrm{ZnSnS}_{4}$ (CZTS) thin films deposited by electrodeposition method," Applied Mechanics and Materials, vol. 343, pp. 85-89, 2013.

[15] I. Muneer, M. A. Farrukh, S. Javaid, M. Shahid, and M. Khaleequr-Rahman, "Synthesis of $\mathrm{Gd}_{2} \mathrm{O}_{3} / \mathrm{Sm}_{2} \mathrm{O}_{3}$ nanocomposite via sonication and hydrothermal methods and its optical properties," Superlattices and Microstructures, vol. 77, pp. 256-266, 2015.

[16] R. Brayner, F. Fiévet, and T. Coradin, "Synthesis of organic and bioorganic nanoparticles: an overview of the preparation methods," in Nanomaterials: A Danger or a Promise? A Chemical and Biological Perspective, J. Allouche, Ed., pp. 27-74, Springer, London, UK, 2013.

[17] V. Parashar, R. Parashar, B. Sharma, and A. C. Pandey, "Parthenium leaf extract mediated synthesis of silver nanoparticles: a novel approach towards weed utilization," Digest Journal of Nanomaterials and Biostructures, vol. 4, no. 1, pp. 45-50, 2009.

[18] T. Klaus-Joerger, R. Joerger, E. Olsson, and C.-G. Granqvist, "Bacteria as workers in the living factory: metal-accumulating bacteria and their potential for materials science," Trends in Biotechnology, vol. 19, no. 1, pp. 15-20, 2001.

[19] K. S. Kavitha, S. Baker, D. Rakshith et al., "Plants as green source towards synthesis of nanoparticles," International Research Journal of Biological Sciences, vol. 2, no. 6, pp. 66-76, 2013. 
[20] U. Bandyopadhyay, K. Biswas, I. Chattopadhyay, and R. K. Banerjee, "Biological activities and medicinal properties of neem (Azadirachta indica)," Current Science, vol. 82, no. 11, pp. 1336-1345, 2002.

[21] W.-H. Chun, Y.-C. Chang, L.-J. Yang et al., "Clinicopathologic features of skin reactions to temporary tattoos and analysis of possible causes," Archives of Dermatology, vol. 138, no. 1, pp. 8892, 2002.

[22] O. A. Habbal, A. A. Al-Jabri, and A. G. El-Hag, "Antimicrobial properties of Lawsonia inermis (henna): a review," Australian Journal of Medical Herbalism, vol. 19, no. 3, pp. 114-125, 2007.

[23] I. Abulyazid, E. M. E. Mahdy, and R. M. Ahmed, "Biochemical study for the effect of henna (Lawsonia inermis) on Escherichia coli," Arabian Journal of Chemistry, vol. 6, no. 3, pp. 265-273, 2013.

[24] T. Debnath, P. J. Park, N. C. Deb Nath, N. B. Samad, H. W. Park, and B. O. Lim, "Antioxidant activity of Gardenia jasminoides Ellis fruit extracts," Food Chemistry, vol. 128, no. 3, pp. 697-703, 2011.

[25] S. J. Choi, M.-J. Kim, H. J. Heo et al., "Ameliorating effect of Gardenia jasminoides extract on amyloid beta peptide-induced neuronal cell deficit," Molecules and Cells, vol. 24, no. 1, pp. 113118, 2007.

[26] R. A. A. Lelono, S. Tachibana, and K. Itoh, "Isolation of antifungal compounds from Gardenia jasminoides," Pakistan Journal of Biological Sciences, vol. 12, no. 13, pp. 949-956, 2009.

[27] P. S. George, G. A. Ravishankar, and L. V. Venkataraman, "Clonal multiplication of Gardenia jasminoides Ellis through axillary bud culture," Plant Cell Reports, vol. 13, no. 1, pp. 59-62, 1993.

[28] R. Farzinebrahimi, Tissue culture and biological activities of Gardenia jasminoides Ellis [M.S. thesis], University of Malaya, Kuala Lumpur, Malaysia, 2012.

[29] S. A. Mahdy, Q. J. Raheed, and P. T. Kalaichelvan, "Antimicrobial activity of zero valent iron nanoparticles," International Journal of Modern Engineering Research, vol. 2, no. 1, pp. 578-581, 2012.

[30] V. K. Sharma, K. M. Siskova, and R. Zboril, "Magnetic bimetallic Fe/Ag nanoparticles: decontamination and antimicrobial agents," in Interactions of Nanomaterials with Emerging Environmental Contaminants, vol. 1150 of ACS Symposium Series, chapter 11, pp. 193-209, American Chemical Society, Washington, DC, USA, 2013.

[31] K. R. Reddy, H. M. Jeong, and A. V. Raghu, "Synthesis of MWCNTs-core/thiophene polymer-sheath composite nanocables by a cationic surfactant-assisted chemical oxidative polymerization and their structural properties," Journal of Polymer Science, Part A: Polymer Chemistry, vol. 48, no. 7, pp. 1477-1484, 2010.

[32] O. Mahapatra, S. Ramaswamy, S. V. K. Nune, T. Yadavalli, and C. Gopalakrishnan, "Corn flake-like morphology of iron nanoparticles and its antibacterial property," The Journal of General and Applied Microbiology, vol. 57, no. 1, pp. 59-62, 2011.

[33] V. V. Makarov, A. J. Love, O. V. Sinitsyna et al., "“Green” nanotechnologies: synthesis of metal nanoparticles using plants," Acta Naturae, vol. 6, no. 1, pp. 35-44, 2014.

[34] S. Ahmad, M. A. Farrukh, M. Khan, M. Khaleeq-ur-Rahman, and M. A. Tahir, "Synthesis of iron oxide-tin oxide nanoparticles and evaluation of their activities against different bacterial strains," Canadian Chemical Transactions, vol. 2, no. 2, pp. 122133, 2014.

[35] S. Shah, M. N. Chandraprabha, and K. Samrat, "Synthesis and characterization of zero valent iron nanoparticles and assessment of its antibacterial activity," International Review of Applied Biotechnology and Biochemistry, vol. 2, no. 1, pp. 145-151, 2014.

[36] M. Sampath, R. Vijayan, E. Tamilarasu, A. Tamilselvan, and B. Sengottuvelan, "Green synthesis of novel jasmine bud-shaped copper nanoparticles," Journal of Nanotechnology, vol. 2014, Article ID 626523, 7 pages, 2014.

[37] D. P. Suhas, H. M. Jeong, T. M. Aminabhavi, and A. V. Raghu, "Preparation and characterization of novel polyurethanes containing 4,4'-oxy-1,4-diphenyl bis(nitromethylidine)diphenol schiff base diol," Polymer Engineering and Science, vol. 54, no. 1, pp. 24-32, 2014.

[38] S. Rajendran, M. Agasta, R. B. Devi, B. S. Devi, K. Rajam, and J. Jeyasundari, "Corrosion inhibition by an aqueous extract of Henna leaves (Lawsonia Inermis L)," Zaštita Materijala, vol. 50, pp. 77-84, 2009.

[39] M. A. Farrukh, S. Ali, and M. K. Rahman, "Photodegradation of 2,4,6-trinitrophenol catalyzed by $\mathrm{Zn} / \mathrm{MgO}$ nanoparticles prepared in aqueous-organic medium," Korean Journal of Chemical Engineering, vol. 30, no. 11, pp. 2100-2107, 2013.

[40] Z. S. Basinski, W. Hume-Rothery, and A. L. Sutton, "The lattice expansion of iron locality: synthetic sample: at $T=1033 \mathrm{~K}$," Proceedings of the Royal Society of London, vol. 229, pp. 459-467, 1955. 

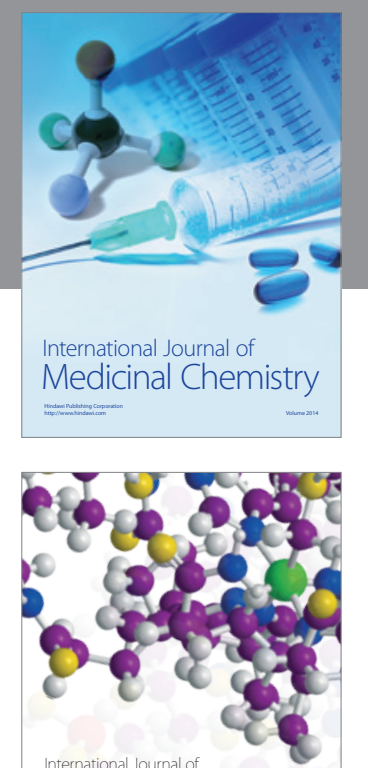

\section{Carbohydrate} Chemistry

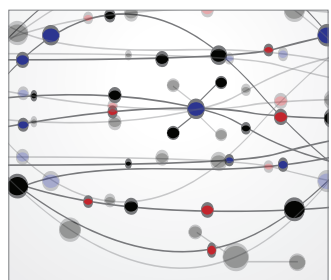

The Scientific World Journal
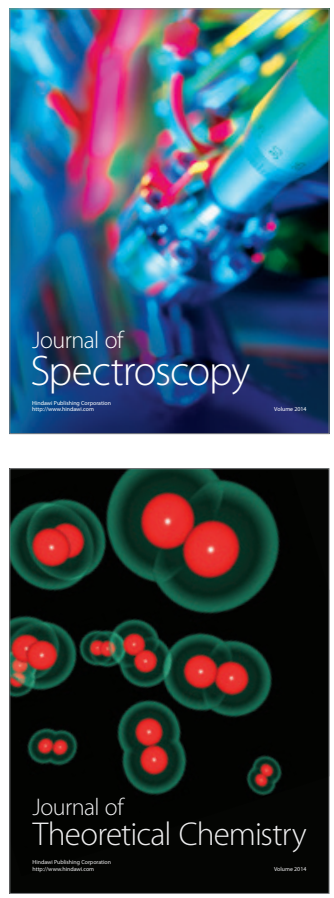
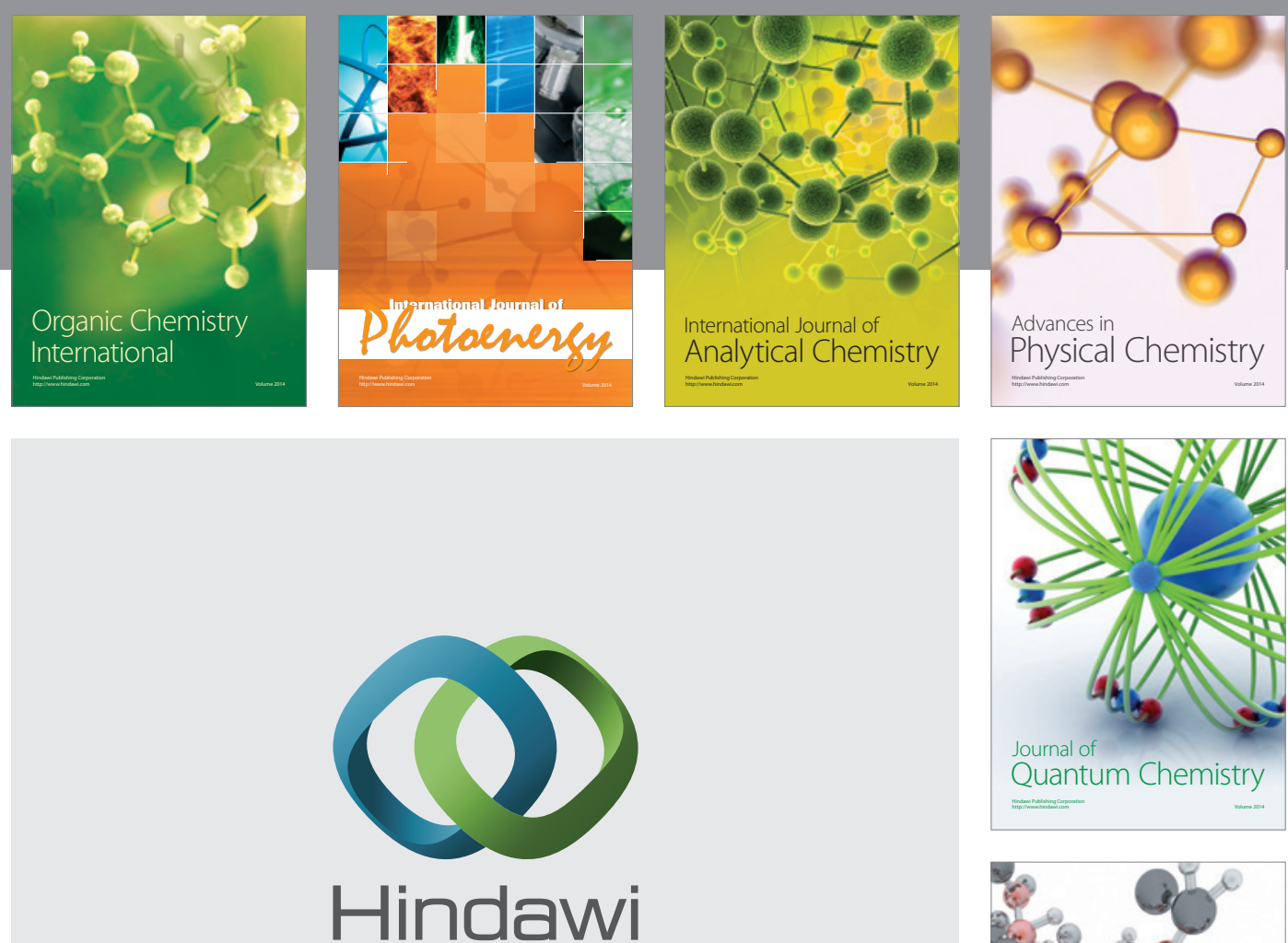

Submit your manuscripts at

http://www.hindawi.com

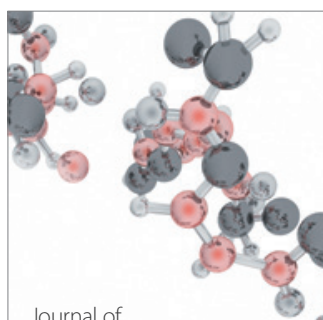

Analytical Methods

in Chemistry

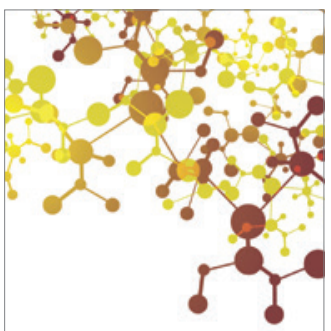

Journal of

Applied Chemistry

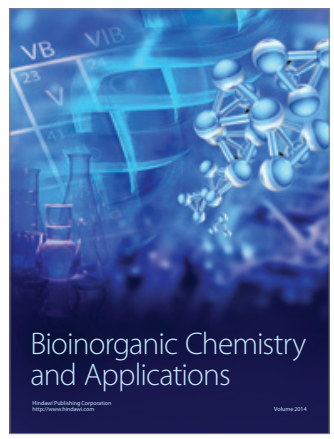

Inorganic Chemistry
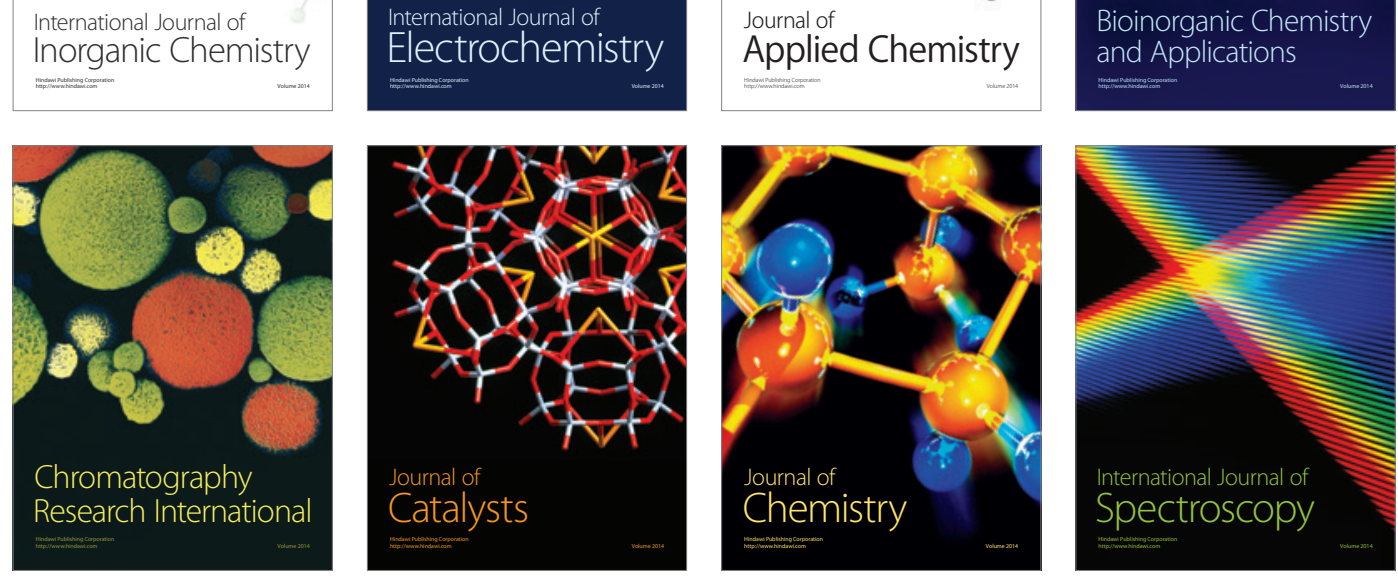